\title{
Relapsing Polychondritis
}

\author{
Internal Medicine Division of Hospital São Paulo, Escola Paulista de Medicina of \\ Universidade Federal de São Paulo - São Paulo, Brazil
}

\begin{abstract}
Purpose: This article describes a clinically-diagnosed case of relapsing polychondritis (RP), attended at the Hospital São Paulo, and presents a literature review of the subject. Source of research: The literature review was made via Medline (1990-96), Lilacs (198096), textbooks of rheumatology, and some articles about the history of the disease. In Medline, 113 articles from 1990 to 1996 were found, and there were 23 articles from 1980 to 1996 in Lilacs. Research procedure: We reviewed the articles available at BIREME (Biblioteca Regional de Medicina) with the primary focus being on the disease in question. Summary: RP is a rare disease of unknown etiology described initially by Jackson-Wartenhorst in 1923 and characterized by a recurrent and acute inflammatory process that causes the collapse of the cartilaginous structures and their subsequent replacement by fibrous connective tissue. The cartilage most commonly attacked is that of the auricle of the ear and nasal septum, while the cartilage of the trachea, larynx, epiglottis, ribs, and articulations may also be involved. Ocular inflammations and systemic reactions with fever are also described. In 1976, McAdam presented a complete prospective study of 23 patients, reviewed the 136 cases described up until that time, and then proposed diagnostic criteria which were later expanded by Damiani and Levine. Currently, more than 500 cases have been described. Conclusion: Although a rare disease, better knowledge of it is needed, as RP may be lethal with tracheal collapse and obstruction of respiratory pathways, making precise diagnosis and adequate therapeutic intervention necessary.
\end{abstract}

UNITERMS: Relapsing polychondritis.

\section{CASE REPORT}

A white Brazilian male, aged 31, fireman, native of Terra Boa, Parana, and resident of Poa, São Paulo, was interned on July 3, 1996. The patient came to the hospital with a history of chest pain for one month.

Eleven months before this, with no prior symptoms, the patient began to feel stabbing pains localized in the region between the shoulder blades, which worsened with movement and physical force. Ten months before

Address for correspondence:

Lincoln Sakiara Miyasaka

Rua Teodoro Sampaio, 972 - casa 18

São Paulo/SP - Brasil - CEP 05406-050 internment, pain and redness in the left eye appeared. The patient then consulted a physician who said it was an allergy and prescribed prednisone $20 \mathrm{mg}$. During this period, the patient received a light trauma to the nose which provoked an intense, but painless edema. It was observed that, with the use of the prescribed medication, all of the symptoms disappeared, but left as a sequel a depression in the nose. Two months before internment, the patient stopped taking the medication and immediately the pain reappeared in his back at a high intensity, and also appeared in the wrists and knees. One month before internment, in addition to the pain in the back, wrists and knees, the patient began to experience chest pain which was aggravated by palpation and deep breathing, a daily fever of $38.5-39.0^{\circ} \mathrm{C}$, sweating, chills, lack of appetite, prostration, weight loss ( $7 \mathrm{~kg}$ in one month, $13 \mathrm{~kg}$ total), 
dry cough and dyspnea when coughing. The patient denied having addictions to tobacco or alcohol.

Physical examination showed the patient to be in regular general condition, fever $\left(38^{\circ} \mathrm{C}\right)$, slimmed, eupneic, anemic, $\mathrm{HR}=94$, arterial blood pressure $11 / 8 \mathrm{~cm}$ of $\mathrm{Hg}$.

On his face, a depression in the nose was observed (photo). A decrease of vesicular murmur in both lungs without abnormal rale was noted. There was no alteration in the heart, nor in the abdomen. There was pain in the articulations of the knees, wrists, and costo-condral articulations without local heat or redness.

\section{LABORATORY FINDINGS}

Creatinin $=0.5 \mathrm{mg} / \mathrm{dl} ;$ Potassium $=4.5 \mathrm{mEq} /$; sodium $=143 \mathrm{mEq} / \mathrm{l}$; Bilirrubin $\mathrm{T}=0.4, \mathrm{D}=0.2, \mathrm{I}=0.2 \mathrm{GOT}=9$ $\mathrm{U} / \mathrm{l}, \mathrm{GPT}=11 \mathrm{U} / \mathrm{l}$; Erythrocyte count $=4.4 \times 10 / \mathrm{mm}^{3}$;
$\mathrm{Hb}=12.2 \mathrm{~g} / \mathrm{dl} ; \mathrm{Ht}=38 \% ; \mathrm{MCH}=27.73 \mathrm{pg} ; \mathrm{MCHC}=$ $32.11 \mathrm{~g} / \mathrm{dl} ; \mathrm{MCV}=86.36$; platelet $=394,000$; leukocyte $=14,100$ (neut $=76$, eos $=3$, bas $=0$, limph $=12$, mono $=$ 9); $\mathrm{Alb}=3.1 \mathrm{~g} / \mathrm{dl}$; Urinalysis: $\mathrm{pH}=6.5, \mathrm{D}=1020$, prot (), gluc(-), leukocytes $=12,000 / \mathrm{ml}$, erythrocytes $=800,000 /$ $\mathrm{ml}$ dismorphism (-), calcium oxalate crystals = few; calcium $=284 \mathrm{mg}$ in $1,620 \mathrm{ml}$ urine in $20 \mathrm{~h}$; uric acid = $729 \mathrm{mg}$ in $1,620 \mathrm{ml}$ of urine in $20 \mathrm{~h}$.

Antinuclear antibody (-), anti native DNA antibody $(-)$, anti ENA antibody (U1-RNP, anti-Sm, anti SS-A/Ro, anti-SS-B/La) $=(-) ;$ CH50 = $188 \mathrm{U}(130-330)$; Rheumatoid factor (-); cryoglobulin (-); anticardiolipin antibody (-); ANCA (-); C reactive protein $=1 / 16$; LE cels $(-)$; Mucoprotein $=5.3$; anti streptolisin $0<200 \mathrm{UI} / \mathrm{ml}$; VDRL $(-)$; urine protein excretion $(-)$; creatinin clearance $=124$ $\mathrm{ml} / \mathrm{min} / 1.73 \mathrm{~m}$; urine culture (-).

Total protein $=6.7(6-8 \mathrm{~g} / \mathrm{dl}), \mathrm{Alb}=2.91(3.2-5.6)$; alpha $1=0.21(0.1-0.4)$; alpha $2=1.27(0.4-1.1)$; beta $=1.13(0.1-1.2) ;$ gamma $=1.18(0.5-1.6) ;$ Erythrocyte
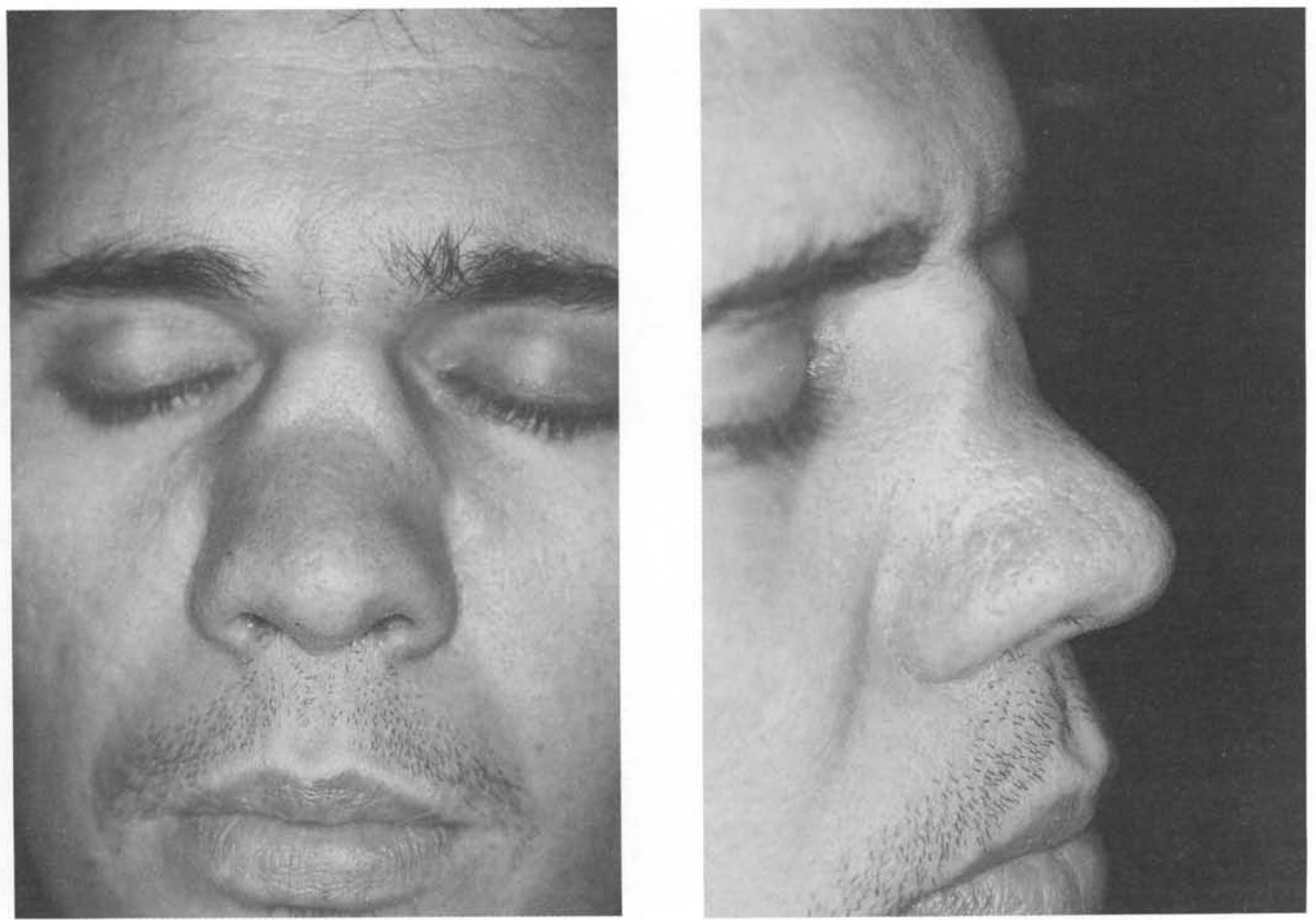

Figure - "Saddle" aspect of the nose. 
sedimentation rate $=53(1-7 \mathrm{~mm} / \mathrm{h}) ;$ acid alpha 1 glucoprotein $=395(43-130 \mathrm{mg} / \mathrm{dl})$.

Prothrombin Time $=80.8(>70 \%) ; \mathrm{RNI}=1.19 ;$ PTT $=1.0(<1.25)$; Bleeding Time = $1(1-3 \mathrm{~min})$; coagulation time $=7$ (4-9).

$\mathrm{X}$ ray examination of facial bones showed the nasal bone without alteration, and cartilage hipoplasia. Ophthalmologic examination showed episcleritis in the left eye.

Renal biopsy results were: optic and immunofluorescence microscopy normal.

\section{EVOLUTION}

Diagnosis of relapsing polychondritis (RP) was made clinically on July 9, 1996, and treatment with prednisone $1 \mathrm{mg} / \mathrm{kg}$ ( $60 \mathrm{mg}$ per day) started. There was a prompt subsidence of articular pain, fever and general condition, with only hoarseness remaining.

The patient is now being followed up as an outpatient receiving $40 \mathrm{mg}$ of prednisone per day.

\section{LITERATURE REVIEW}

\section{Epidemiology}

The prevalence of RP is equal among men and women. It has been described in all races but is more frequent among Caucasians ${ }^{(17)}$.

\section{Clinical Findings ${ }^{(6-12)}$}

RP is characterized by acute inflammatory episodes of cartilaginous structures that might recover spontaneously, but that frequently relapse and culminate with the destruction of its structure. It may present systemic involvement with fever, weight loss, and other organs such as central nervous system, kidneys, respiratory tract, and blood vessels.

The most frequent clinical features of 2 literature reviews with 159 and 112 cases were summarized by Andres J Politi (Table 1).

The most frequent clinical feature in both series is auricular chondritis. The auricular pavilion is swollen,

\section{Table 1}

Clinical features in the course of relapsing polychondritis $^{(6)}$ : comparison of 2 series

\begin{tabular}{lrc}
\hline & $\begin{array}{c}\text { Mc Adam } \\
\mathrm{n}=159\end{array}$ & $\begin{array}{c}\text { Isaak } \\
\mathrm{n}=112\end{array}$ \\
\hline Auricular Chondritis & $88.6 \%$ & $85 \%$ \\
Arthritis & $81 \%$ & $52 \%$ \\
Nasal Chondritis & $72.4 \%$ & $54 \%$ \\
Ocular Manifestation & $65.4 \%$ & $51 \%$ \\
Larynx- Tracheal & $55.9 \%$ & $48 \%$ \\
Inner Ear & $45.9 \%$ & $43 \%$ \\
Cardiopathy & $11.9 \%$ & $6 \%$ \\
Vasculopathy & $16.3 \%$ & $14 \%$ \\
Nephropathy & $\mathrm{NR}$ & $26 \%$ \\
\hline
\end{tabular}

$\mathrm{n}=$ number of patients

painful and angry-red in colour. In $95 \%$ of cases it is bilateral. It may provoke the narrowing of the external auditive canal. The ear lobe is preserved. The process may subside spontaneously, or it may destroy the cartilage, leaving a "cabbage-like" appearance. It may present as a poly or oligoarthritis.

Nasal chondritis leads to the destruction of the cartilaginous portion of the nasal septum, giving the nose a "saddle-like" appearance.

The ocular alterations are unspecific, such as conjunctivitis, uveitis, retinopathies, optical neuritis, palpebral edema, and proptosis. Episcleritis is the most frequent, occurring in 39 per cent of cases ${ }^{(21)}$.

Respiratory manifestations are hoarseness, dyspnea, a choking sensation, wheezing, and pain in the laryngotracheal articulations. These can provoke obstruction through three mechanisms: edema of the glottis, trachea and bronchi; formation of a fibrous mass in the airways; and collapse of the tracheal cartilage. The obstruction is complicated by infection.

Hearing loss may be experienced due to obstruction of the external auditory canal, middle ear otitis, or by affliction of the auditory branch of the VIII cranial nerve due to vasculitis. Nausea, dizziness, vomiting, and ataxia by neuritis of the cochlear branch due to vasculitis may also be present.

Vasculitis is also found in some cases of RP. According to Michet, systemic vasculitis is the most frequent associated inflammatory syndrome ${ }^{(17)}$ but this was not Politi's finding in his summary of 271 cases of polychondritis ${ }^{(6)}$. There are cases described of aortal and mitral insufficiency, but these are rare. 
Table 2

Diseases associated with relapsing polychondritis

\begin{tabular}{lr}
\hline Rheumatoid Arthritis & $5 \%$ \\
Sjogren's Syndrome & $3.1 \%$ \\
Systemic Lupus Erithematous & $1.25 \%$ \\
Systemic Sclerodermia & $1.25 \%$ \\
Psoriatic Arthritis & $1.25 \%$ \\
Raynaud's Syndrome & $1.25 \%$ \\
Thyroiditis & $5 \%$ \\
Ulcerative Colitis & $1.88 \%$ \\
Glomerulonephritis & $1.25 \%$ \\
Disgammaglobulinemia & $1.25 \%$ \\
Pernicious Anemia & $0.62 \%$ \\
Neoplasm & $3.1 \%$ \\
Other & $6.9 \%$ \\
\hline
\end{tabular}

In a review of 129 patients with RP, 29 presented affected kidneys. Mesangial expansion, cellular proliferation, and necrotizing glomerulonephritis were observed. Electron microscopy detected dense deposits at the mesangial level, and direct immunofluorescence revealed $\mathrm{C} 3$ and IgM in the mesangio ${ }^{(6)}$.

Neurological manifestations include ophthalmic neuritis of the oculomotor, facial and auditive-vestibular neuritis, headaches, encephalopathy, convulsions, hemiparesias and ataxias.

\section{Associated Diseases}

Approximately 25 percent of RP cases are associated with other diseases, with the following being the most common according to Politi.

\section{Complementary Exams}

No complementary exam is diagnostic for RP; all are only slightly sensitive and specific. Their utility is only to discard other pathologies and recognize other ailments.

The erythrocyte sedimentation rate and reactive $\mathrm{C}$ protein are the best exams to accompany the evolution of the disease. Tadaki et al studied the composition of urinary glucosaminoglican and found an elevation of dermatan sulphate and hyaluronic acid, both of skin origin in the active phases of the disease and not the 4-6 sulphate condroitin that would be expected in cases of cartilage destruction ${ }^{(24)}$. So further studies are necessary in this area.

Antibodies to type II collagen have been reported to correlate with the activity of the disease ${ }^{(20)}$.
Histopathology

The histopathological findings are diagnostic. During the active phase, there is a loss of cartilage metacromasis, chondral and perichondral necrosis, infiltration by the polymorphonuclear neutrophils, plasmacytes, lymphocytes, apoptotic bodies, and perichondral hemorrhage. In the advanced stage, there is cicatrical repair with lymphohistiocytic infiltration, fibrosis, deposit of hemosiderin and loss of elastic tissue. Studies with direct immunofluorescence revealed positivity for $\operatorname{IgA}$, IgM, IgG and $\mathrm{C} 3$, suggesting the presence of circulating immune complexes ${ }^{(22,23)}$.

\section{Etiopathogenesis}

The etiopathogenesis is not clear, but there are indications of auto-immune involvement. RP is associated with auto-immune diseases in $25 \%$ of cases; immunoglobulins and lesion complements are encountered, as are type II anticollagen antibodies in the serum of patients with active RP. Clinical improvement occurs with immunosuppression therapy.

\section{Differential Diagnosis}

Considering the general clinical situation, the most difficult differential diagnosis is with Wegener's granulomatosis (WG) and other systemic vasculitis. WG is manifested as a systemic vasculitis with collapse of the nasal wall, arthritis, and affliction of the respiratory system. WG can be differentiated by the presence of granulomas, involvement of lungs and kidneys, and the lack of auricular pavilion involvement.

The "saddle" nose can also be found in WG and leishmaniosis, advanced congenital syphilis, lupus, sarcoidosis, the lepromatous type of leprosy, basocellular epitheliomas, cocaine inhalation, aspergilosis and paracoccidioidomicosis.

\section{Prognosis}

The five-year survival rate is 74 per cent ${ }^{(14)}$. The most frequent reason for death is infection of the respiratory tract, secondary to the bronchial obstruction and the use of corticosteriods. Other causes are systemic vasculitis, acute respiratory insufficiency due to respiratory collapse, and renal insufficiency due to glomerulonephritis.

\section{Treatment}

The treatment of RP consists of the use of nonsteriod anti-inflammatories and low dose 
corticosteroids in situations of mild auricular/nasal chondritis or arthritis. For cases with serious manifestations such as laryngotracheal or ocular symptoms, inner ear inflammation, severe auricular or nasal chondritis, systemic vasculitis, aortitis or glomerulonephritis, prednisone at a dose of $1 \mathrm{mg} / \mathrm{kg} /$ day is indicated. The use of immunosuppressors such as azathioprine and cyclophosphoamide is reserved for those patients refractory to steroid therapy ${ }^{(13)}$. The use of dapsona, colchicina ${ }^{(15)}$, anti-CD4 monoclonal antibody, D-penicillamine and antimalarials has also been described. The increasing number of successful reports of cyclosporin $\mathrm{A}$ in a dose of $15 \mathrm{mg} / \mathrm{kg} /$ day suggests that it may be the best tolerated and potentially most reliable drug for the corticosteroid-resistant patient ${ }^{(14,16)}$. Nebulized racemic ephedrine is an option used successfully in cases of acute subglotic edema ${ }^{(19)}$. Continuous positive airway pressure masks may provide relief of severe dyspneic symptoms ${ }^{(17)}$.

\section{DISCUSSION}

$\mathrm{RP}$ is a rare disease seldom described in the literature. Only 500 cases have been published worldwide up until now. In Brazil, only four articles were encountered from 1990-96 (search by Lilacs).

Histological diagnosis is made with difficulty because cartilage material cannot be obtained for analysis, or because findings are uncharacteristic, principally in the advanced stages when there is destruction of the structures and their replacement by fibrosis. When there is no possibility of a histological diagnosis, it must be made clinically. According to Damiani and Levine, this clinical diagnosis can be confirmed by:

1) Three of McAdam's criteria: bilateral auricular chondritis, polychondritis, nasal chondritis, ocular inflammation (conjunctivitis, scleritis, episcleritis, uveitis or queratitis), chondritis of the respiratory tract or involvement of the VII cranial nerve, even without histological confirmation;

2) One or more of McAdam's criteria with histological confirmation;

3) Two or more affected sites with response to treatment with corticoids or dapsona.

The case in question presents four of McAdam's criteria: nasal chondritis, polychondritis, episceritis, and chondritis of the respiratory tract, in addition to the immediate response to corticotherapy. In spite of not having histological confirmation, we were able to make the diagnosis clinically. The hematuria with negative dysmorphism and elevated urinary calcium was interpreted as being due to urinary microcalculi, which improves the prognosis.

The patient is being followed as an outclinic patient, due to the possibility of relapses, renal involvement, and airway obstruction, all of which would require rapid intervention.

\section{RESUMO}

Objetivo: O propósito deste artigo e a descrição de um caso com diagnostico clinico de Policondrite Recorrente atendido no Hospital São Paulo e realizar uma revisão da literatura sobre o tema. Fonte de dados: A pesquisa foi feita através do Medline(1990-96) e Lilacs (1980-96) buscando os temas Policondrite Recorrente, e Policondrite Recidivante, alem de livros textos de reumatologia e artigos mais antigos sobre a historia da moléstia. Seleção dos estudos: No Medline foram encontrados 113 artigos publicados em inglês, espanhol, e português entre 1990 e 1996 . No Lilacs foram encontrados 23 artigos entre 1980 e 1996. Coleta dos dados: Foram analisados os artigos disponiveis na BIREME cujo enfoque primário era a moléstia em questão. Síntese dos dados: Policondrite recorrente é uma doença rara de etiologia desconhecida descrita inicialmente por Jacksch-Wartenhorst em 1923 e caracterizada por um processo inflamatório agudo e recorrente de cartilagens que provoca o desabamento das estruturas cartilaginosas e sua substituição por tecido conjuntivo fibroso. As cartilagens mais comumente acometidas são do pavilhão auricular e septo nasal, embora as cartilagens da traquéia, laringe, epiglote, arcos costais e articulações também possam estar envolvidas. Inflamaçōes oculares e reaçōes sistêmicas como febre também sāo descritas. Em 1976, Mc Adam apresentou um estudo prospectivo completo de 23 pacientes e revisou os 136 casos descritos até aquela época, propondo critérios diagnósticos que foram logo ampliados por Damiani e Levine. Atualmente já foram descritos mais de 500 casos. Conclusão: Mesmo sendo uma doença rara, há necessidade de maior divulgação na classe médica desta afecção, pois a policondrite recorrente pode se tornar letal por colapso traqueal e obstrução das vias respiratórias, sendo que um diagnóstico preciso e uma intervenção terapêutica adequada se fazem necessários. 


\section{REFERENCES}

1. Person CM, Kline HM, Victor D. Newcomer. Relapsing Polychondritis. The New England Journal of Medicine 1960;263:51-58.

2. Kaye RL, Sones DA. Relapsing Polychondritis. Clinical and Pathologic Features in Fourteen Cases. Annals of Internal Medicine 1964;60(4):653-664.

3. Dolan DL, Lemmon GB, Teitelbaum SL. Relapsing Polychondritis. Analytical Literature Review and Studies on Pathogenesis. American Journal of Medicine 1966;41:285-297.

4. Retamar RA, Leon AR, Spiner RE, Magnin PH. Estado Actual de la Policondritis Cronicas Recurrente dos Nuveas Observaciones. Rev Arg Derm 1993;74:85-96.

5. Michet CJ. Vasculitis and Relapsing Polychondritis. Rheumatic Disease Clinics of North America 1990; 16(2):441-444.

6. Politi AJ. Polycondritis Recidivantes Revisión Crítica. Archivos Argentinos de Dermatología 1993;T.XLIII:73-91.

7. Pereira MD, Araujo CM, Silva RC, Azevedo JRGM, Ferreira MAT, Resende PS, Amaral MJCS, Pedroso ERP. Associação entre Policondrite Recidivante e Tuberculose Tratada com Corticóide e Ciclofosfamida - Relato de Um Caso. Rev Méd Minas Gerais 1994;4(4):58-60.

8. Self J, Hammarsten JF, Lyne B, Peterson DA, Paul ST. Relapsing Polychondritis. Arch Intern Med 1967; 120:109-112.

9. Parrochia EB. Policondritis Atrofiante. Bol Hosp S J de Dios 1994;41(5):330-331.

10. Gibson GJ. Rare Rheumatic Disorders. Relapsing Polychondritis. Baillieres Clin Rheumatol 1993;7:179-181.

11. Freedman SF, Amedee RG. Relapsing Polychondritis. J La State Med Soc 1992;144:131-133.
12. Perez MS, Lario AB, Lopez AJ, Valdinelso AJL. Acta Otorrinolaringol Esp 1992;43:21-26.

13. Karpman WJ. Arthritis and Allied Condition. A Textbook of Rheumatology, $13^{\text {th }}$ ed. $1996 ; 1595-1603$.

14. Klippel JH, Dieppe PA. Rheumatology, 1994;6.31.1-6.31.4.

15. Goihman-Yahr M. Relapsing Polychondritis Responding to Colchine. Int J Dermatology 1994;33(6):448-9.

16. Ormerod AD, Clark LJ. Relapsing Polychondritis treatment with cyclosporin A. British Journal of Dermatology 1992;127:300-301.

17. Michet CJ. Relapsing Polychondritis of Koopman WJ Arthritis and Allied Conditions. A Textbook of Rheumatology, $13^{\text {th }}$ ed. 1997;82:1595-1603.

18. Valenzuela R, Cooperrider PA, Gozate P, et al. Relapsing Polychondritis. Human Pathol 1980;11:19-22.

19. Gaffney RJ, Harrison M, Path FRC, Blayney AW. Nebulized Racemic Ephedrine in the Treatment of Acute Exacerbation of Laryngeal Relapsing Polychondritis. J Laryng Otol 1992;106:63-64.

20. Foidart JM, Abe S, Martin GR et al. Antibodies to type II collagen in relapsing polycondritis. New England Journal of Medicine 1978;299:1203-1207.

21. Issak BL, Liesegang TJ, Michet CJ. Ocular and Systemic Findings in Relapsing Polychondritis. Ophthalmology 1986;93:681-689.

22. Foidart JM, Katz SJ. Subtle clues to diagnosis by immunopathology: relapsing polychondritis. Am J Dermathopathol 1979;1:257-260.

23. Bergfeld WF. Relapsing Polychondritis with positive direct immunofluorescence. Arch Dermatol 1978;114:127.

24. Tadaki T, Aiba S, Igarashi M, Tagami H. Analysis of increased urinary acid glycosaminoglicans in a patient with relapsing polychondritis. Acta Derm Venereol 1987; 67:441-445. 